Immunological and Microwear Analysis of Chipped-Stone Artifacts from Piedmont Contexts

Author(s): Michael Petraglia, Dennis Knepper, Petar Glumac, Margaret Newman and Carole Sussman

Source: American Antiquity, Vol. 61, No. 1 (Jan., 1996), pp. 127-135

Published by: Society for American Archaeology

Stable URL: http://www.jstor.org/stable/282307

Accessed: 22-07-2016 09:42 UTC

Your use of the JSTOR archive indicates your acceptance of the Terms \& Conditions of Use, available at

http://about.jstor.org/terms

JSTOR is a not-for-profit service that helps scholars, researchers, and students discover, use, and build upon a wide range of content in a trusted digital archive. We use information technology and tools to increase productivity and facilitate new forms of scholarship. For more information about JSTOR, please contact support@jstor.org.

Society for American Archaeology is collaborating with JSTOR to digitize, preserve and extend access to American Antiquity 


\title{
IMMUNOLOGICAL AND MICROWEAR ANALYSIS OF CHIPPED-STONE ARTIFACTS FROM PIEDMONT CONTEXTS
}

\author{
Michael Petraglia, Dennis Knepper, Petar Glumac, Margaret Newman, and Carole Sussman
}

\begin{abstract}
Immunological and microwear analysis was performed on 100 chipped-stone artifacts from four prehistoric sites located in the Virginia Piedmont. A total of 20 artifacts returned positive results for immunological analysis and 16 artifacts returned microwear results. The findings indicate the negative effects of postdepositional processes and the potential utility of the techniques for deciphering prehistoric activities, otherwise unavailable by conventional studies in piedmont contexts. The study further illustrates the value and problems associated with immunological and microwear analyses on chipped-stone assemblages.
\end{abstract}

Cien artefactos líticos procedentes de cuatro sitios ubicados en el piedemonte de Virginia fueron sometidos a los análisis inmunológicos y de micro-desgaste. Del análisis inmunológico se obtuvieron resultados positivos con 20 artefactos y del análisis de micro-desgaste 16 artefactos demostraron indicios de desgaste. Los resultados de los análisis muestran los efectos negativos de los procesos después de la deposición. Además indican la utilidad potencial de estas técnicas, la cual no existe con métodos convencionales para revelar las actividades prehistóricas en contextos similares. El estudio muestra el valor y los problemas asociados con análisis inmunológicos y de micro-desgaste en conjuntos líticos.

$\mathrm{M}$ ost prehistoric sites in the Mid-Atlantic region of the eastern United States contain only chipped-stone artifacts. The lithic assemblages usually consist of high proportions of debitage and low numbers of formal tools, hindering inferences as to the types of activities carried out at various locations. While artifacts produced from cryptocrystalline materials such as chert, jasper, and chalcedony sometimes occur at these sites, lithic assemblages usually contain artifacts made from crystalline materials such as quartz and quartzite, which do not often lend themselves to easy functional identification. Moreover, many prehistoric sites in the MidAtlantic region are located in the Piedmont zone, a physiographic province characterized by shallow soil development. This setting inhibits preservation of features, activity area distributions, and faunal and floral remains. As a result, site interpretation and behavioral reconstruction based exclusively on material remains are often ambiguous. However, the growth of specialized tech- niques, including immunological and microwear analyses, presents new opportunities for deriving functional information from these sites.

\section{Immunological and Microwear Techniques}

Aboriginal peoples employed chipped stone in a wide range of activities, leaving behind material residues and mechanical wear and damage on the surfaces of stone tools. Prehistorians have recognized that these potential sources of functional information may be preserved on stone tools after hundreds if not thousands of years in archaeological context. Consequently, immunological and microwear techniques have been developed to extract residues and detect prehistoric uses.

\section{Immunology}

A suite of techniques have been used to decipher animal and plant residues on archaeological samples (e.g., Briuer 1976; Broderick 1979; Downs 1985; Heron et al. 1991; Hyland et al. 1990; Newman and Julig 1989; Shafer and Holloway

Michael Petraglia, Dennis Knepper, and Petar Glumac • Cultural Resources Department, Parsons Engineering Science, 10521 Rosehaven Street, Fairfax, VA 22030

Margaret Newman • Department of Archaeology, University of Calgary, Calgary, Alberta T2N 1N4, Canada

Carole Sussman - Department of Anthropology, University of California, San Diego, La Jolla, CA 92093-0101 
1979; Smith and Wilson 1990; Tuross and Dillehay 1995). However, analysts continue to debate the sensitivity and potential of particular techniques (e.g., Downs and Lowenstein 1995; Eisele 1994; Fiedel 1996; Newman et al. 1996; Smith and Wilson 1992; Tuross et al. 1996). Crossover immunoelectrophoresis (CIEP), the immunological technique used in the current study, has been shown to be a potentially valid method for examining prehistoric protein residues. Positive replicable results have been obtained from residue analysis on archaeological materials from sites of differing ages and soil conditions (Kooyman et al. 1992; Newman 1990; Newman and Julig 1989; Newman et al. 1993; Nolin et al. 1994; Yohe et al. 1991). Tests of the validity of CIEP have demonstrated that immunological specificity is retained and identification is possible even where protein degradation has occurred (Kooyman et al. 1992).

Experiments have recently been conducted to produce independent, objective tests for the study of protein residues and preservation conditions. Experimental studies have begun to detail the relationship between residue analysis and the amount and condition of protein remaining on an artifact, soil types, and taphonomic conditions (Cattaneo et al. 1993; Gurfinkel and Franklin 1988; Inashima 1992). While these studies clearly indicate the complicated nature of residue preservation, the experimental results corroborate the notion that proteins may be preserved for some period of time, rendering accurate identifications.

\section{Microwear}

Microwear studies on stone tools attempt to identify traces of use through various types of polish (e.g., Beyries 1987; Keeley 1980; Moss 1983; Sussman 1988a; van Gijn 1990; Vaughn 1985). These polishes can be characteristic of the material on which the tool was used, such as hide, wood, soft plant, bone, and antler. The direction in which the polish forms on the surface of the tool, along with observations about edge damage and striations created by use, may reveal the action, such as cutting, scraping, or boring.

While some investigators have questioned the basic validity of microwear as a research tool (Newcomer et al. 1986), most analysts would argue that cultural functions may in fact be determined, recognizing that polishes may be complicated by natural phenomena (e.g., Anderson 1980; Diamond 1979; Kamminga 1979; LeviSala 1986; Mansur 1983; Meeks et al. 1982; Plisson and Mauger 1988; Sussman 1988a). Since microwear is easiest to detect on fine-grained lithic materials, most studies have employed cryptocrystalline materials such as flint, chert, and chalcedony (e.g., Anderson-Gerfaud 1983; Beyries 1982; Keeley 1980; Moss 1983; Vaughn 1985). Recently, however, microwear studies and experiments have been expanded to include quartz and its crystalline counterpart, quartzite, indicating the ability of the materials to show signs of use (Knutsson 1988; Sussman 1985, 1988a, 1988b).

\section{Archaeological Sites}

The archaeological materials used for immunological and microwear analysis were recovered from excavations carried out at four prehistoric sites (44PW546, 44PW554, 44PW592, 44LD459) in the Piedmont region of northern Virginia, $25 \mathrm{~km}$ west of Washington, D.C. The prehistoric sites occur along upland streams that flow toward the Potomac River, the major perennial drainage. Temporally diagnostic lithic artifacts and radiocarbon dates placed major site occupations from the Early Archaic to the Late Woodland, spanning a period of nearly 10,000 years. The artifacts occurred in buried horizons varying in depth from $20 \mathrm{~cm}$ to $1 \mathrm{~m}$. Horizontal dimensions of the sites varied from 4,015 to $12,710 \mathrm{~m}^{2}$. A total of 9,800 chipped-stone artifacts was recovered from the four sites, ranging from a low of 600 to a high of 5,900 . Organic preservation at the sites was minimal; some carbonized remains were recovered, but no faunal remains were preserved. Full descriptions of the excavations and artifact assemblages may be found in the major technical report (Petraglia et al. 1993).

\section{Procedures}

The excavated artifacts from the four Virginia sites were treated with minimal handling in the field and immediately bagged. The artifacts were not treated or cleaned in any fashion before laboratory cataloging. A total of 100 chipped-stone 
Table 1. Artifact Types.

\begin{tabular}{lccccrr}
\hline Site & Core & Flake & BiFace & Point & Uniface & Total No. (\%) \\
\hline 44PW546 & 2 & 7 & - & 16 & - & $25(25 \%)$ \\
44PW554 & 1 & 6 & 4 & 10 & 4 & $25(25 \%)$ \\
44PW592 & 1 & 15 & 8 & 1 & - & $25(25 \%)$ \\
44PW459 & 1 & 8 & 2 & 14 & - & $25(25 \%)$ \\
Totals & $5(5 \%)$ & $36(36 \%)$ & $14(14 \%)$ & $41(41 \%)$ & $4(4 \%)$ & $100(100 \%)$ \\
\hline
\end{tabular}

Table 2. Raw Material Types.

\begin{tabular}{|c|c|c|c|c|c|c|}
\hline Site & Quartz & Quartzite & Chert & Jasper & Chalcedony & Total No. $(\%)$ \\
\hline 44PW546 & 3 & 5 & 15 & 2 & - & $25(25 \%)$ \\
\hline 44PW554 & 23 & - & 1 & 1 & - & $25(25 \%)$ \\
\hline 44PW592 & 17 & 6 & 1 & 1 & - & $25(25 \%)$ \\
\hline 44PW459 & 18 & - & 2 & 1 & 4 & $25(25 \%)$ \\
\hline Totals & $61(61 \%)$ & $11(11 \%)$ & $19(19 \%)$ & $5(5 \%)$ & $4(4 \%)$ & $100(100 \%)$ \\
\hline
\end{tabular}

artifacts, 25 from each of the four Virginia sites, was selected for analysis. Selection of 100 pieces was considered an adequate sample in light of the fact that most other immunological studies employ from 7 to 36 artifacts (e.g., Gramly 1991; Kooyman et al. 1992; Newman and Julig 1989; Yohe et al. 1991), and microwear studies traditionally average 30 to 50 artifacts (Keeley 1980; Sussman 1988a).

Since a goal of this study was to demonstrate the utility of the immunological and microwear analyses for examining lithic assemblages from Piedmont sites, most of the artifacts selected were thought to have the greatest potential for use. Many were projectile points or other bifacial or unifacial tools with visible edge damage (Table 1). In addition to formal tools, cores and a number of flakes with and without visual edge damage were chosen. Positive information derived from debitage was considered important because it would support inferences that a proportion of the material classified as waste was used as tools.

Five lithic raw material types were selected following relative proportions occurring in the four sites: quartz dominated the sample, followed by chert, quartzite, jasper, and chalcedony (Table 2). Positive information derived from crystalline materials (i.e., quartz, quartzite) was considered especially significant since these materials have been understudied because of the difficulty of determining function from visual examination.

The 100 chipped-stone artifacts were first subjected to immunological analysis, followed by microwear. Detailed discussion of the methodolo- gies employed for the immunological and microwear analyses may be found in the site report (Petraglia et al. 1993). The antisera used for immunological testing were bear (Ursidae), bovine (Bos), cat (Felidae), chicken (Tetraonidae), deer (Cervidae), dog (Canidae), duck (Anatidae), elk (Cervus canadensis), guinea pig (Rodentia), human (Hominidae), mouse (Sigmodontidae), pigeon (Aves), rabbit (Lagomorpha), rat (Rodentia), trout (Salmonidae), and fern. The most probable animals represented by certain antisera for the eastern United States are listed in Table 3. For the microwear study a microscope with 5,10 , and $20 \times$ objectives and $10 \times$ oculars was used. A Normarski attachment was occasionally used with the $20 \times$ objective to enhance wear features. The chert pieces were scanned at $100 \times$ magnification for traces of polish and edge damage. A magnification of 200X was used for interpretation of polishes. The highly reflective nature of the quartz tools required a magnification of $200 \times$ both for location and identification of wear features. Lower

Table 3. Relationship of Animals to Antisera Used in Analysis.

\begin{tabular}{ll}
\hline Antisera & Most Probable Animals \\
\hline Bear & brown or black \\
Cat & bobcat, lynx, mountain lion \\
Chicken & turkey, quail, grouse, pheasant \\
Deer & deer, elk, moose, caribou \\
Dog & wolf, fox, dog \\
Guinea pig & porcupine, squirrel, beaver \\
Rabbit & rabbit, hare \\
Rat & rat, mouse
\end{tabular}

Note: Certain antisera may produce reactions with species in the same family or closely related families. 

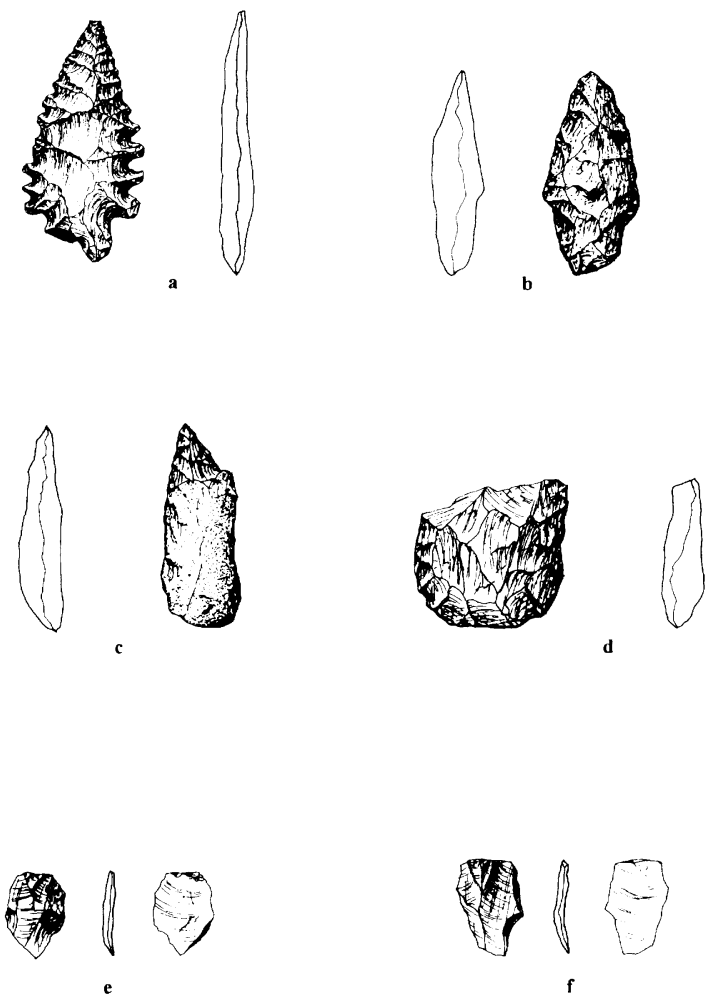

$0 \quad 12 \mathrm{~cm}$

Figure 1. Examples of artifact types testing positive to immunology: (a, b) projectile points $(3237-3,3091-54)$; (c, d) bifaces (3091$55,3182-37)$; (e, f) flakes $(7006-1,7605-1)$.

magnification study of quartz (e.g., 100×) sometimes resulted in problems associated with surface irregularity and reflectivity, making it impossible to recognize polish features. Identification of polish attributes tended to be more accurate at 200X. Microphotography was used for reference and comparative purposes. A reference collection of archaeological and experimentally derived quartz and chert tools was employed for identification (Sussman 1985, 1988a, 1988b).

\section{Results}

The laboratory analyses verified that residues and mechanical wear and damage could be recognized on 32 artifacts. The immunological and microwear results therefore provided insight into faunal exploitation and stone tool use.

\section{Immunology}

Negative reactions to pre-immune serum on the soils from the four sites indicated no obvious contaminants. Of the 100 chipped stones, 20 artifacts returned positive results to animal antisera, seven to duck, five to deer, four to rabbit, three to dog, three to rodent (i.e., rat, guinea-pig), two to cat, one to bear, and one to human (Table 4). The identified faunal types are in accordance with known prehistoric and modern animal ranges for the Mid-Atlantic region. Each site yielded from four to six positive returns, suggesting that different depositional contexts and ages did not affect reactions. Positive results were derived from 10 projectile points, six bifaces, one uniface, and three flakes (Figure 1).

\section{Microwear}

Of the 100 chipped-stone artifacts submitted, 16 had signs of microwear, showing mechanical damage indicative of use, or polishes indicative of hafting or potential contact materials (Table 4). Five 
Table 4. Immunological and Microwear Results.

\begin{tabular}{|c|c|c|c|c|c|c|c|c|}
\hline Site & $\begin{array}{l}\text { Catalog } \\
\text { Number }\end{array}$ & $\begin{array}{l}\text { Class } \\
\text { Type }\end{array}$ & $\begin{array}{c}\text { Raw } \\
\text { Material }\end{array}$ & $\begin{array}{l}\text { CIEP } \\
\text { Result }\end{array}$ & $\begin{array}{c}\text { Post- } \\
\text { Deposition }^{\mathrm{a}}\end{array}$ & $\begin{array}{l}\text { Inferred } \\
\text { Use }\end{array}$ & $\begin{array}{c}\text { Hafting } \\
\text { Traces }\end{array}$ & $\begin{array}{c}\text { Contact } \\
\text { Material }^{\mathrm{b}}\end{array}$ \\
\hline 44PW546 & $471-1$ & point & chert & - & $\mathrm{YC}$ & projectile & - & bone \\
\hline 44PW546 & $481-1$ & point & chert & - & - & projectile & yes & hide/meat \\
\hline 44PW546 & $7006-1$ & flake & jasper & rabbit, cat & - & - & - & - \\
\hline 44PW546 & $7138-1$ & point & jasper & deer, rabbit & $\mathrm{G}$ & - & - & - \\
\hline 44PW546 & $7154-1$ & point & chert & - & - & projectile & yes & ?bone \\
\hline 44PW546 & $7283-1$ & point & chert & bear, rabbit & $\mathrm{G}$ & - & yes & - \\
\hline 44PW546 & $7420-1$ & point & chert & - & YC & projectile & yes & bone \\
\hline 44PW546 & $7445-1$ & point & quartzite & $\operatorname{dog}$ & YC & - & - & - \\
\hline 44PW546 & $7605-1$ & flake & chert & rabbit & $\mathrm{G}$ & - & - & - \\
\hline 44PW546 & $7757-1$ & point & quartz & guinea pig & YC & - & - & - \\
\hline 44PW546 & $7768-1$ & flake & quartz & - & - & cutting/slicing & - & - \\
\hline 44PW546 & $7989-1$ & point & chert & - & - & - & yes & - \\
\hline 44PW554 & $3011-1$ & point & chert & - & $\mathrm{G}, \mathrm{YC}$ & - & yes & - \\
\hline 44PW554 & $3019-74$ & flake & quartz & - & YC & scraper & - & hide \\
\hline 44PW554 & $3020-1$ & point & quartz & - & YC & projectile & - & wood/hide/?bone \\
\hline 44PW554 & $3057-4$ & uniface & quartz & deer & $\mathrm{YC}$ & endscraper & - & wood/hide \\
\hline 44PW554 & $3091-54$ & point & quartz & duck & - & - & - & - \\
\hline 44PW554 & $3091-55$ & biface & quartz & duck & - & - & - & - \\
\hline 44PW554 & $3182-37$ & biface & quartz & duck & - & - & - & - \\
\hline 44PW554 & $3183-33$ & point & quartz & - & YC & projectile & - & - \\
\hline 44PW554 & $3237-3$ & point & jasper & duck & $\mathrm{G}$ & - & - & - \\
\hline 44PW554 & $3315-16$ & uniface & quartz & - & - & endscraper & - & hide/wood \\
\hline 44PW592 & $8000-1$ & flake & quartz & dog/duck/human & - & - & - & - \\
\hline 44PW592 & $8065-1$ & biface & chert & duck & G & - & - & - \\
\hline 44PW592 & $8065-2$ & biface & quartz & duck & - & - & - & - \\
\hline 44PW592 & $8065-4$ & flake & quartz & - & $\mathrm{YC}$ & cutting/scraping & - & wood/hide \\
\hline 44PW592 & $8130-1$ & biface & quartz & mouse, rat & YC & - & - & - \\
\hline 44PW592 & $8280-1$ & biface & quartzite & $\operatorname{dog}$ & YC & - & - & - \\
\hline 44LD459 & $6115-1$ & point & quartz & deer & $\mathrm{YC}$ & projectile & - & - \\
\hline 44LD459 & $6274-1$ & point & chert & cat & $\mathrm{G}$ & - & - & - \\
\hline 44LD459 & $6357-1$ & point & quartz & deer & - & projectile & yes & hide/bone/wood \\
\hline 44LD459 & $6377-1$ & point & chalcedony & deer & $\mathrm{G}, \mathrm{YC}$ & - & - & - \\
\hline
\end{tabular}

${ }^{\mathrm{a}} \mathrm{G}=$ glossy appearance; $\mathrm{YC}=$ yellow crystalline substance.

${ }^{\mathrm{b}} \mathrm{A}$ backslash (/) designates overlapping wear features produced experimentally (polish is absent).

artifacts were deemed unsuitable for analysis: two were rejected because they were too large for the microscope stage; one was extremely crystalline and hence too reflective to examine; and two were patinated with a heavy gloss that obscured potential use traces.

Of the artifacts with microwear, 11 were morphologically classified as projectile points, two as unifaces, and three as flakes. Based on mechanical damage, 13 artifacts had inferred uses, eight as projectiles, three as scrapers, and two as cutting/slicing or cutting/scraping implements. A total of 10 artifacts had identifiable contact materials, including one hide, two wood/hide, one hide/wood, one wood/hide/bone, one hide/bone/wood, one hide/meat, two bone, and one with probable bone (Table 4). Multiple contact materials on artifacts are inferred since experiments indicate that patterns of wear and polish often overlap during early stages of development. While the collection had a number of quartz projectile points, which may have been used for hunting given their morphological shapes, traces of wear on these artifacts were not particularly distinct. On quartz tools, those indicating hide and wood working share many of the same characteristics in the early stages of use (pitting, linear grooves, and surface roughness) (Sussman 1988a). The interpretation of the contact material therefore cannot be more explicit than "hide/wood," for example, unless discernible traces of bone polish (such as found on a few chert points) were located. Eleven projectile points bore signs of use and hafting (Figure 2a-c). Based on morphology and wear patterns, two of the unifaces were shown to be used 

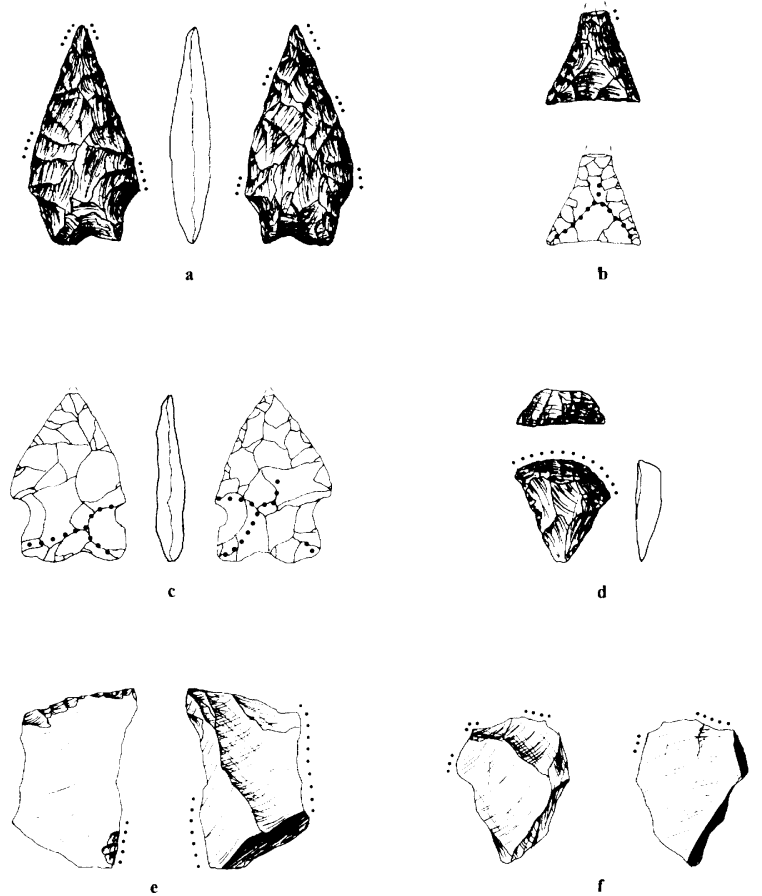

$0 \quad 1 \quad 2 \mathrm{~cm}$

Figure 2. Examples of artifact types with microwear. External dots indicate use wear and internal dots indicate haft wear: $(a, b, c)$ projectile points (3020-1, 7420-1, 3011-1); (d) uniface (3057-4); (e, f) flakes $(8065-4,7768-1)$.

as endscrapers (Figure 2d). Importantly, the microwear study indicated that debitage was used, three flakes bearing signs of use (Figure $2 \mathrm{e}-\mathrm{f}$ ). Although 48 artifacts had signs of postdepositionally altered surfaces, 20 of these had positive results, 10 artifacts bearing signs of material uses and polishes and 13 having identifiable protein residues (Table 4 ).

\section{Discussion and Conclusion}

Combined immunological and microwear analysis was conducted on a set of artifacts in order to examine the degree to which information could be extracted about prehistoric activities from a class of sites usually studied only by conventional descriptive means. The immunological results indicated the type of information that archaeologists may expect for addressing questions of prehistoric subsistence from a sample of chipped-stone artifacts. Specifically, the results showed that duck protein was present on an Early
Archaic (10,000-8500 B.P.) projectile point, and duck and deer residues were identified on two Late Archaic (5000-3000 B.P.) projectile points. Cat and deer were identified on two Early/Middle Woodland (3000-1000 B.P.) points, and deer, rabbit, dog, and rodents were identified on three Late Woodland (1000 to 400 B.P.) points. The identification of duck residues, in accordance with the upland stream habitats, is of particular importance given that no reliable economic scenarios have been put forth by archaeologists establishing use of waterfowl in these particular upland settings. The presence of duck in Archaic sites and the presence of a diversity of fauna in Woodland contexts may signal differences in exploitation strategies or possibly changes in paleoenvironments. If the information provided in this study were supplemented by additional immunological studies, a larger regional database could be established, thereby supporting or refuting hypotheses about prehistoric subsistence. 
Analysis of the immunological and microwear results by morphological type indicated the information potential of certain artifact classes. The most consistent results were obtained from bifaces (i.e., projectile points, bifaces) and unifaces versus debitage (i.e., cores, flakes). Of the 41 projectile points submitted for analysis, 10 ( 24 percent) provided immunological results and 11 (27 percent) displayed microwear. The projectile points showed hafting traces and development of polishes, both indicative of long-term use or curation. Of the 14 bifaces submitted, six (43 percent) had positive immunological results. None had signs of microwear, indicating that while many bore residues, they were not curated or used to such a degree as to produce polishes. Of the four unifaces analyzed, one ( 25 percent) had a positive immunological reaction and two (50 percent) had microwear. Of the debitage, none of the five cores had positive results, supporting the inference that these items were used for flake production and not directly as tools. Of the 36 flakes submitted for analysis, three ( 8 percent) had positive immunological reactions and three ( 8 percent) had microwear signs. While a lower frequency of flakes produced positive results compared to bifaces, the findings indicated that these pieces, morphologically classed as debitage, were indeed used. One flake produced a positive reaction to cat, two to rabbit, and one to dog, duck, and human. Three other flakes had microwear evidence, indicating cutting and slicing, scraping against hide, and cutting and scraping against wood or hide. Given that most Mid-Atlantic assemblages usually consist of a relatively large proportion of chipped-stone debitage and a relatively small number of formal tools (i.e., points, bifaces), this study shows positively that a percentage of the flakes were used for expedient tasks, replacing formally manufactured curated tools in certain activities. Immunological and microwear results may therefore enhance and redefine notions about the function of chippedstone types.

In terms of use by raw material, comparisons reveal variation between cryptocrystalline (i.e., chert, jasper, chalcedony) and crystalline materials (i.e., quartz, quartzite). The 28 cryptocrystalline materials produced eight (29 percent) positive immunological reactions and seven $(25$ percent) had microwear results. On the other hand, the 72 crystalline materials produced 12 (17 percent) positive immunological reactions and nine ( 12.5 percent) had microwear results. The fine-grained materials, therefore, had the greater chance for positive results. The discrepancy in microwear results between the materials may not be the result of cultural uses, but may be due to the difficulty of identifying use wear on cryptocrystalline materials and the problems of analyzing quartz and quartzite, where polishes are not as readily preserved or as easily identified by the analyst. Despite the fact that quartz and quartzite had lower percentages of positive results, these materials generally fared well, indicating that important information survives on these materials. The finding of residues and microwear on quartz and quartzite tools from the Virginia sites is important since these are the predominant material types in this region. The positive results for the crystalline materials used in this study are also important in light of the fact that polishes on quartz from previous analyses conducted on Lower Paleolithic sites in the Old World have not produced encouraging results. The negative results on the Old World material may be attributed to the effects of the greater length of burial time, where soil chemicals and abrasion alter polishes (Sussman 1988b).

The immunological and microwear results indicate that useful data may be extracted to examine preservation variability among sites in different contexts. The immunological results from the Virginia sites (20 percent) was slightly lower than the range reported from other studies in plains grassland, boreal forest, and dry cave contexts, which produced positive identifications on 25 to 30 percent of the analyzed implements (Kooyman et al. 1992; Newman 1990; Newman and Julig 1989). The microwear study showed that postdepositional processes, especially chemical alterations, were operating at the sites, probably resulting in organic degradation. Although the Virginia sample cannot be directly compared to others because of varying sample sizes and analyzed tool types, comparative studies may lead to a better understanding of preservation conditions among sites of different ages, depositional contexts, and environments.

The results specifically point to the relationship between postdepositional processes in altering 
positive results. While the microwear study indicated that virtually none of the tools was abraded (indicating a low energy, primary context situation), there was evidence for natural modifications, as observed in other contexts (e.g., Kamminga 1979; Levi-Sala 1986; Meeks et al. 1982). A glossy patination was present on 12 percent ( 12 chert, jasper, chalcedony) of the Virginia specimens and a yellow/brown crystalline substance was present on 36 percent ( 24 quartz, 10 chert, 2 quartzite) of the artifacts. The alterations were predominately related to chemical processes, indicating the high potential for organic deterioration. The fact that 80 artifacts did not test positively for immunological results also tends to support evidence for degradation processes.

Overall, the current study demonstrates the potential utility of conducting immunological and microwear analysis on sites consisting of chippedstone assemblages, suggesting directions for future research on prehistoric economies and site formation. Owing to factors of soil acidity and the relative absence of features, macrobotanical and faunal data were poor at the sites, a situation encountered throughout the eastern United States and in many other geographic regions. Thus, the immunological and microwear analysis of tools from the sites provided access to potential subsistence and functional data, which is otherwise unavailable. While the exact interpretations derived from these techniques may be debated, data obtained from the present study substantially augmented site analyses. Although future emphasis should be placed on additional experimentation to refine immunological and microwear studies, analyses of this kind do appear to provide important comparative data for archaeologists, indicating the quality of information that may be derived from assemblages dominated by chipped stone. Archaeologists must continue to research these new methodologies to find improved ways of learning more about the past.

Acknowledgments. The archaeological excavations and analyses described herein were carried out by the Cultural Resources Department of Parsons Engineering Science, with funding from the Consolidated Natural Gas (CNG) Transmission Corporation. The field and laboratory investigations were carried out by numerous individuals, all of whom cannot be acknowledged here but who are credited in the technical reports. Valuable comments were provided by
Michael Graves, James Adovasio, Dave Hyland, and several anonymous reviewers. All errors or shortcomings in this article are the responsibility of the authors.

\section{References Cited}

Anderson, $\mathrm{P}$

1980 A Testimony of Prehistoric Tasks: Diagnostic Residues on Stone Tool Working Edges. World Archaeology 12:181-194

Anderson-Gerfaud. $\mathrm{P}$

1983 A Consideration of the Uses of Certain Backed and "Lustered" Stone Tools from Late Mesolithic and Natufian Levels of Abu Hureya and Mureybet (Syria). In Traces de l'Utilisation sur les Outiles Neolithiques du Proche Orient, edited by M.-C. Cauvin, pp. 77-106. Maison de l'Orient Mediterranean, Lyon. France.

Beyries, $\mathrm{S}$.

1982 Comparison de Traces d'Utilisation sur Differentes Roches Siliceuses. In Recent Progress in Microwear Studies. Praehistorica Belgica, pp. 235-240. Musée Royale de l'Afrique Centrale, Tervuren, Belgium.

1987 Variabilite de L'Industrie au Moustérian. BAR International Series 328. British Archaeological Reports. Oxford.

Briuer, F. L.

1976 New Clues to Stone Tool Function: Plant and Animal Residues. American Antiquity 41:478-484.

Broderick, M

1979 Ascending Paper Chromatographic Technique in Archaeology. In Lithic Use-Wear Analysis, edited by B. Hayden, pp. 375-383. Academic Press, New York

Cattaneo, C.. K. Gelsthorpe, P. Phillips, and R. J. Sokol

1993 Blood Residues on Stone Tools: Indoor and Outdoor Experiments. World Archaeology 25:29-43.

Diamond, G.

1979 The Nature of So-Called Polished Surfaces on Stone Artifacts. In Lithic Use-Wear Analysis, edited by B. Hayden, pp. 159-166. Academic Press, New York

Downs, E. F

1985 An Approach to Detecting and Identifying Blood Residues on Archaeological Stone Artifacts: A Feasibility Study. Center for Materials Research in Archaeology and Ethnology, Massachusetts Institute of Technology, Cambridge, Massachusetts.

Downs, E. F., and J. M. Lowenstein

1995 Identification of Archaeological Blood Proteins: A Cautionary Note. Journal of Archaeological Science 22:11-16

Eisele, J.

1994 Survival and Detection of Blood Residue Analysis on Stone Tools. Technical Report 94-1. Department of Anthropology, University of Nevada, Reno.

Fiedel, S. J.

1996 Blood from Stones? Some Methodological and Interpretive Problems in Blood Residue Analysis Journal of Archaeological Science 23:139-147.

Gramly, R. M.

1991 Blood Residues Upon Tools from the East Wenatchee Clovis Site, Douglas County, Washington. Ohio Archaeologist 41(4):4-9.

Gurfinkel, D. M., and U. M. Franklin

1988 A Study of the Feasibility of Detecting Blood Residues on Artifacts. Journal of Archaeological Science 15:83-97.

Heron. C. L.. R. P. Evershed. L. J. Goad, and V. Denham 
1991 New Approaches to the Analysis of Organic Residues from Archaeological Remains. In Archaeological Sciences 1989, edited by P. Budd, B. Chapman, R. Janway, and B. Ottaway, pp. 332-339. Oxbow Monograph 9. Oxbow, Oxford, England.

Hyland, D. C., J. M. Tersak, J. M. Adovasio, and M. I. Siegel 1990 Identification of the Species of Origin of Residual Blood on Lithic Material. American Antiquity 55:104-112

Inashima, P. Y

1992 A Preliminary Summary of Organic Residue Studies and Their Application on Lithic Materials from the Northern Blue Ridge. Quarterly Bulletin of the Archeological Society of Virginia 47:179-192.

Kamminga, J.

1979 The Nature of Use-Polish and Abrasive Smoothing on Stone Tools. In Lithic Use-Wear Analysis, edited by B. Hayden, pp. 143-157. Academic Press, New York.

Keeley, L. H.

1980 Experimental Determination of Stone Tool Uses: A Microwear Analysis. University of Chicago Press, Chicago.

Knutsson, $\mathrm{K}$

1988 Patterns of Tool Use. Scanning Electron Microscopy of Experimental Quartz Tools. Societas Archaeologica Upsaliensis, Uppsala, Switzerland.

Kooyman, B., M. E. Newman, and H. Ceri

1992 Verifying the Reliability of Blood Residue Analysis on Archaeological Tools. Journal of Archaeological Science 19:265-269.

Levi-Sala, I.

1986 Use-wear and Post-depositional Surface Modification: A Word of Caution. Journal of Archaeological Science 13:229-244.

Mansur, E.

1983 Scanning Electron Microscopy of Dry Hide Working Tools: The Role of Abrasives and Humidity in Microwear Polish. Journal of Archaeological Science 10:223-230.

Meeks, N. D., G. Sieveking, M. S. Tite, and J. Cook

1982 Gloss and Use-Wear Traces on Flint Sickles and Similar Phenomena. Journal of Archaeological Science 9:317-340.

Moss, E. H.

1983 The Functional Analysis of Flint Implements. BAR International Series 177. British Archaeological Reports, Oxford.

Newcomer, M. H., R. Grace, and R. Unger-Hamilton

1986 Investigating Microwear Polishes with Blind Tests. Journal of Archaeological Science 13:203-218.

Newman, M. E.

1990 The Hidden Evidence from Hidden Cave, Nevada. Unpublished Ph.D. dissertation, University of Toronto, Toronto.

Newman, M. E., and P. Julig

1989 The Identification of Protein Residues on Lithic Artifacts from a Stratified Boreal Forest Site. Canadian Journal of Archaeology 13:119-132.

Newman, M. E., H. Ceri, and B. Kooyman

1996 The Use of Immunological Methods to Detect Archaeological Residues: A Reply to Eisele. Antiquity, in press.

Newman, M. E., R. M. Yohe, H. Ceri, and M. Q. Sutton 1993 Immunological Protein Residue on Nonlithic Archaeological Materials. Journal of Archaeological Science 20:93-100.
Nolin, L., J. K. G. Kramer, and M. E. Newman

1994 Detection of Animal Residues in Humus Samples from a Prehistoric Site in the Lower Mackenzie River Valley, Northwest Territories. Journal of Archaeological Science 21:403-412.

Petraglia, M. D., D. A. Knepper, and P. Glumac

1993 Prehistoric Occupations in the Piedmont: Archaeological Excavations in Fauquier, Prince William and Loudoun Counties, Virginia. Submitted to Virginia Department of Historic Resources, Richmond Copies available from Parsons Engineering Science, Fairfax, Virginia.

Plisson, H., and M. Mauger

1988 Chemical and Mechanical Alterations of Microwear Polishes: An Experimental Approach. Helinium 28:3-16.

Shafer, H. J., and R. G. Holloway

1979 Organic Residue Analysis in Determining Stone Tool Function. In Lithic Use-Wear Analysis, edited by B. Hayden, pp. 385-399. Academic Press, New York.

Smith, P. R., and M. T. Wilson

1990 Detection of Haemoglobin in Human Skeletal Remains by ELISA. Journal of Archaeological Science $17: 255-268$

1992 Blood Residues on Ancient Tool Surfaces: A Cautionary Note. Journal of Archaeological Science 19:234-241

Sussman, C

1985 Microwear on Quartz: Fact or Fiction? World Archaeology 17:101-111.

1988a A Microscopic Analysis of Use-Wear and Polish Formation on Experimental Quartz Tools. BAR International Series 395. British Archaeological Reports, Oxford.

1988b Aspects of Microwear as Applied to Quartz. In Industries Lithiques, edited by S. Beyries, pp. 3-27. BAR International Series 411. British Archaeological Reports, Oxford

Tuross, N., I. Barnes, and R. Potts

1996 Protein Identification of Blood Residues on Experimental Stone Tools. Journal of Archaeological Science, in press.

Tuross, N., and T. D. Dillehay

1995 The Mechanism of Organic Preservation at Monte Verde, Chile, and One Use of Biomolecules in Archaeological Interpretation. Journal of Field Archaeology 22:97-110.

van Gijn, A. L.

1990 The Wear and Tear of Flint: Principles of Functional Analysis Applied to Dutch Neolithic Assemblages. Unpublished Ph.D. dissertation, Rijksuniversiteit te Leiden, The Netherlands.

Vaughn, $\mathrm{P}$

1985 Use-Wear Analysis of Flaked Stone Tools. University of Arizona Press, Tucson.

Yohe, R. M. II, M. E. Newman, and J. S. Schneider

1991 Immunological Identification of Small-Mammal Proteins on Aboriginal Milling Equipment. American Antiquity 56:659-666.

Received October 12, 1994; accepted October 16, 1995. 